\title{
ОЦІНЮВАННЯ СТАНУ МЕНЕДЖМЕНТУ СОЦІАЛЬНОЇ ВІДПОВІДАЛЬНОСТІ ЗА ВНУТРІШНІМИ ВЕКТОРАМИ
}

\section{ASSESSMENT OF THE STATE OF SOCIAL RESPONSIBILITY MANAGEMENT BY INTERNAL VECTORS}

\author{
Надейко Микола Миколайович \\ аспірант, асистент, \\ Львівський університет бізнесу та права \\ ORCID: http://orcid.org/0000-0002-1011-3477
}

Nadeyko Mykola

Lviv University of Business and Law

\begin{abstract}
Оцінка стану менеджменту соціальної відповідальності є першим етапом аналізування цього процесу 3 метою виявлення проблем. У статті окреслено основні засади оцінювання менеджменту соціальної відповідальності за внутрішніми векторами. 3 метою виконання цього завдання використано опитування органів виконавчої влади України щодо соціально орієнтованого бізнесу та експертне оцінювання. Сорормовано методичні засади оцінки стану менеджменту соціальної відповідальності на мікро рівні. Згідно результатів експертного оцінювання ідентифріковано групи підприємств з задовільним, добрим та відмінним станом соціальної відповідальності. Встановлено вагу внутрішніх векторів у процесі соціальної відповідальності. Виявлено основні проблеми процесу оцінювання з точки зору управлінського персоналу підприємства.
\end{abstract}

Ключові слова: соціальна відповідальність, менеджмент соціальної відповідальності, внутрішні вектори у системі корпоративної культури.

Оценка состояния менеджмента социальной ответственности является первым этапом анализа этого процесса с целью выявления проблем. В статье обозначены основные принципы оценки менеджмента социальной ответственности по внутренним векторами. С целью выполнения этой задачи использовано результаты опроса органов исполнительной власти Украины по социально ориентированному бизнесу и экспертная оценка. Сорормированы методические рекомендации оценки состояния менеджмента социальной ответственности на микро уровне. Согласно результатам экспертной оценки идентифицировано группы предприятий с удовлетворительным, хорошим и отличным состоянием социальной ответственности. Установлено вес внутренних векторов в процессе социальной ответственности. Выявлены основные проблемы процесса оценки с точки зрения управленческого персонала предприятия.

Ключевые слова: социальная ответственность, менеджмент социальной ответственности, внутренние векторы в системе корпоративной культуры.

Assessing the state of social responsibility management is the first step in analyzing this process in order to identify problems. The management staff of enterprises realized the expediency of social responsibility. Now it is necessary to form a methodology for evaluating its effectiveness. The article outlines the basic principles of evaluating the management of social responsibility by internal vectors. In order to fulfill this task, surveys of the executive authorities of Ukraine on socially oriented business and expert evaluation were used. Methodical bases of an estimation of a condition of management of social responsibility at micro level are formed. According to the results of the expert assessment, groups of enterprises with a satisfactory, good and excellent state of social responsibility were identified. The assessment of management experts is not affected by the number of projects and the cost of social investment. It is determined that enterprises with the best state of social responsibility have a higher share of income, which is used for this purpose. The weight of internal vectors in the process of social responsibility is established. The main problems of the evaluation process from the point of view of the management staff of the enterprise are revealed. It is determined that due to the lack of uniform evaluation criteria there are no general approaches to assessing the state of social responsibility management. Some experts do not consider it appropriate to assess social responsibility by internal vectors, which can lead to its low efficiency. The vast majority of activities aimed at charity and large image projects are considered to be socially responsible. Low level of understanding of environmental projects as part of corporate social responsibility. Leveling part of the subsystems of corporate cultures of the enterprise in the context of social responsibility. Such as: transparency and completeness of tax payment, the feasibility 
of additional motivation of employees, the formation of a positive psychological climate in the team, the feasibility of improving the quality and environmental friendliness of products offered to customers, responsibility to suppliers.

Keywords: social responsibility, social responsibility management, internal vectors in the system of corporate culture.

Постановка проблеми. Соціальна відповідальність бізнесу, як явище набуло особливого розвитку в умовах пандемії як в Україні так і світі. Через високий рівень залучення до соціальних проектів глобального значення знижується потреба та вмотивованість менеджменту здійснювати заходи соціального спрямування на рівні власного підприємства. 3 іншого боку знизився контроль фріскальних органів за результати внутрішніх підсистем системи корпоративної культури підприємства у частині відповідальності перед працівниками, покупцями та замовниками, сплатою податків, відповідальності за якість та екологічність продукції через меншозначимість у порівнянні 3 іншими проблемами національної економіки. Оцінювання стану менеджменту соціальної відповідальності на рівні підприємства є першим етапом до окреслення напрямків розвитку цього процесу та ідентисрікації проблем.

Аналіз останніх досліджень і публікацій. Методики оцінки корпоративної соціальної відповідальності представлені у роботах таких вітчизняних дослідників, а саме: Березіна О. [1], Буян О. [2], Воробей В. [3], Ворона О. [4], Євтушенко В. [11]. Всі вони схильні до думки, що оцінка має визначати місце у рейтингу соціальної активності в межах певної оціночної системи. Проаналізувавши всі існуючі методики можна стверджувати, що більшість 3 них $є$ трудомісткі через необхідність оцінювання значної кількості критеріїв, що потребує залучення додаткових експертів. Відповідно це несе відповідні матеріальні затрати, що $є$ під силу тільки великим об'єднанням підприємств. Крім того існує ризик значних помилок і похибок у рейтинговому оцінюванні, на якому базується більшість методик через не достатню компетентність експертів. Варто зазначити, що частина методик націлена лише на один вектор менеджменту соціальної відповідальності як у внутрішньому так і зовнішньому середовищі системи корпоративної культури підприємства. На нашу думку, з метою якісної оцінки стану менеджменту соціальної відповідальності варто розпочинати наліз стану соціальної відповідальності на рівні підприємства, а саме 3 власної оцінки експертами 3 числа менеджменту підприємств.

Формулювання цілей статті (постановка завдання). Метою статті $\epsilon$ фрормування методичних рекомендацій щодо оцінювання стану менеджменту соціальної відповідальності на основі експертного оцінювання. До експертного оцінювання пропонуємо долучати як експертів органів виконавчої влади так і управлінський персонал вітчизняних підприємств.

Виклад основного матеріалу дослідження. За даними CorporateRegister.com, найбільшої всесвітньої бази даних нефрінансових звітів, на серпень 2020 року в світі було оприлюднено понад 123183 соціальних звітів 20208 організацій [9]. У порівнянні 3 2008 роком, коли відбувся сплеск нефрінансової звітності, а саме 250 найбільших компаній світу (G250 зі списку Fortune Global 500 за 2007 рік) почали постійно публікувати нефінансові звіти - це значне зростання.

Проблема оцінювання рівня соціальної відповідальності $€$ через відсутність реформування цього процесу. Оскільки немає потреби звітувати перед суспільством, втрачається мотивування звітувати перед собою.

Розпочинати, не залежно від існуючого рівня менеджменту соціальної відповідальності, варто з оцінки цього поняття за внутрішніми векторами.

Якщо розглядати систему корпоративної культури, то в структурі їі підсистем, можна ідентифрікувати такі внутрішні вектори: відповідальність перед персоналом у напрямках забезпечення безпеки праці та охорони здоров'я й мотивування та розвитку персоналу; відповідальність за формування сприятливого психологічного клімату, як всередині колективу так і за його межами (з контрагентами); відповідальність за виконання податкового, митного, господарського, трудового законодавства у процесі господарської діяльності; відповідальність за якість та безпечність продукції перед покупцями та замовниками; відповідальність щодо екологічної безпеки всього процесу виробництва.

3 метою оцінювання цих напрямків соціальної відповідальності варто зазначити, що частина з них $€$ початком одного із зовнішніх векторів, або на перший погляд, дублюють деякі із них. Оцінювання рівня менеджменту соціальної відповідальності за внутрішніми векторами, як вже зазначалось, треба здійснювати у розрізі трьох груп показників, а саме за обсягом інвестицій у заходи соціального спрямування, якістю здійснених заходів та їх ефрективністю. 
Критерії оцінки показників мають відповідати таким вимогам: істотність для даного вектора соціальної відповідальності, кількісний вираз, можливість контролю та перевірки на основі даних обліку, галузева специфріка, зрозумілість для міжнародних користувачів.

Методика оцінювання має складатись 3 двох етапів: оцінки стану менеджменту соціальної відповідальності підприємства на основі експертного оцінювання у розрізі обсягів, якості здійснених заходів та їх ефективності (оцінка рівня менеджменту соціальної відповідальності на основі експертного оцінювання підприємств); ідентифрікації критеріїв оцінки менеджменту соціальної відповідальності за внутрішніми векторами.

Через відсутність необхідності формування нефрінансових звітів немає коректної інфрормації про соціально орієнтовані підприємства крім різного роду рейтингів. Тому ми звернулись зі зверненнями до обласних державних адміністрацій з метою ідентифрікувати по п'ять підприємств, які на їхню думку мають найвищий рівень соціальної відповідальності. У результаті чого ми ідентифрікували 60 підприємств. На ці підприємства було надіслано анкети для експертного оцінювання. У результаті чого ми отримали 34 відповіді.

У межах першого етапу запропонованого дослідження ми намагались дати відповіді на такі запитання: чи співпадають оцінки органів виконавчої влади та суб'єктів господарювання рівня менеджменту соціальної відповідальності? Та - який стан володіння інформацією про обсяги та ефрективність здійснених заходів соціального спрямування за внутрішніми векторами.

Для суб'єктів менеджменту було запропоновано здійснити оцінку стану менеджменту соціальної відповідальності, що характеризується наявністю систематичних заходів соціального спрямування запроваджених та втілених управлінськими структурами. Оцінювання відбувалось згідно шкали від 1 до 10. Задовільний стан менеджменту соціальної відповідальності можна вважати за умови, якщо здійснювані управлінськими структурами заходи соціального спрямування $€$ не систематичні і не мають вираженого впливу на розвиток підприємства. Бальна оцінка знаходиться в межах від 0 до 4. Добрий стан визнається у випадку, якщо здійснювані заходи переважно націлені на соціальний захист персоналу. I носять поодинокий характер щодо зовнішнього спрямування. Бальна оцінка знаходиться в межах від 4 до 7. Від- мінний стан менеджменту соціальної відповідальності визнається за умови, якщо здійснювані заходи носять системний характер і мають як внутрішнє так і зовнішнє спрямування. Бальна оцінка знаходиться в межах від 7 до 10.

Крім того експерти дали відповідь на запитання: яка кількість проєктів соціального спрямування була втілена Вашим підприємством протягом останніх трьох років?; яка частка доходу, у \%, на Вашу думку спрямовується Вашим підприємством на соціальні заходи?

Оскільки, стан менеджменту соціальної відповідальності має безпосередній вплив на ефрективність заходів, що впроваджуються підприємством, то вважатимемо результати експертного оцінювання тотожними есрективності. До уваги брали лише результати експертного опитування тих підприємств, які дали відповідь на другу частину анкети. Відповідно, всі підприємства, що взяли участь в опитуванні розділимо на три групи - залежно від оцінки стану менеджменту соціальної відповідальності (див. табл. 1).

Проаналізувавши вихідні дані та результати наведені у табл. 1 можна зробити такі висновки. На оцінку експертів стану менеджменту соціальної відповідальності не впливає обсяг соціальних інвестицій. Наприклад до групи середнього рівня менеджменту соціальної відповідальності, за експертними оцінками потрапили наприклад підприємства ТОВ Люстдорфр. У свою чергу експерти Вінницького олійно-жировий комбінату оцінили стан менеджменту соціальної відповідальності як задовільний (3 бали) не зважаючи на те, що в середньому $7 \%$ доходу спрямовується на соціальні заходи і протягом останнього року підтримувались 4 проекти на загальну суму 1,5 млн. грн. Значну різницю в інвестиціях підприємств третьої групи можна пояснити тим, що у переважній більшості ті хто вказав значні суми порахували інвестиції пов'язані з впровадженням ресурсозберігаючих технологій або екологічних проектів.

Щодо кількості проектів то для підприємствами першої та другої групи було впроваджено в середньому по 3 проекти, лише підприємствами, що оцінили стан менеджменту соціальної відповідальності відмінно було втілено в середньому більше 4. Це свідчить про те, що експерти н вбачають за необхідне описувати заходи, що втілюються всередині підприємства, що є помилкою.

Частки доходу у різних групах підприємств коливаються від 5 у групі підприємств, що 
Таблиця 1

Результати експертного оцінювання стану менеджменту соціальної відповідальності

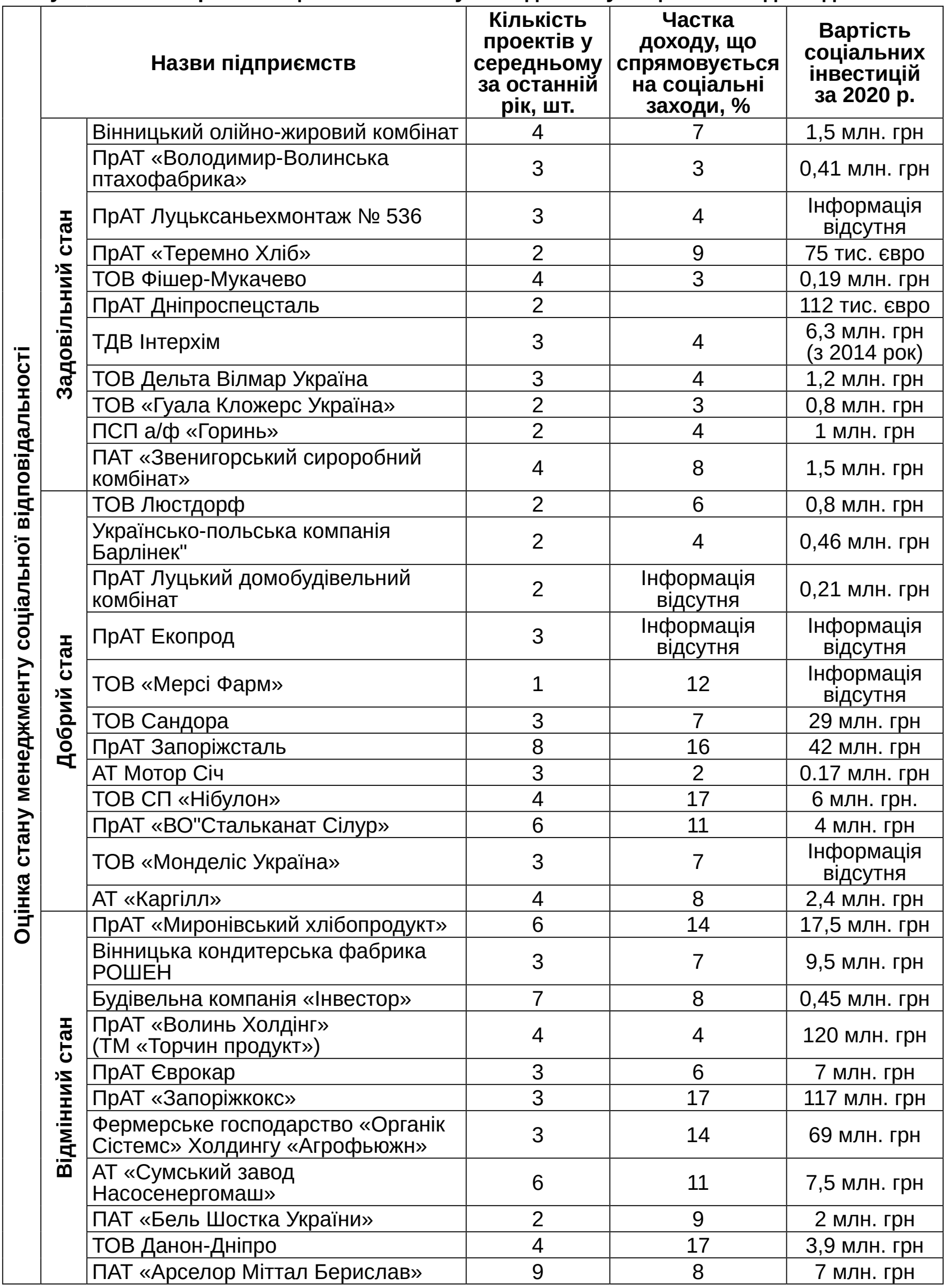

Примітка: ссрормовано автором на основі аналізу відповідей ОДА та анкет експертів від суб'єктів господарювання 
визнають стан менеджменту соціальної відповідальності задовільним до в середньому 10 \% для підприємств з відмінним, на думку експертів станом. Але для другої групи теж притаманні високі частки доходу, які готові витратити на соціальні цілі.

Все зазначене вище, свідчить про те, що у експертів немає єдиних критеріїв оцінки та бачення ситуації щодо втілених заходів соціальної відповідальності.

На прикладі Вінницької області ми бачимо, що не зважаючи на те, що експертами органів виконавчої влади всі п'ять підприємств визнані найбільш соціально орієнтованими, вони за результатами експертного оцінювання розділились на три групи.

У групу з відмінним станом менеджменту соціальної відповідальності потрапили як ПрАТ «Миронівський хлібопродукт» (Вінницька обл.) із зазначеними 6 проектами загальною вартістю 17,5 млн. грн. так і Вінницька кондитерська фрабрика РОШЕН - 3 проекти а суму 1,5 млн. грн. Зрозуміло, що $є$ проекти, які мають протяжність декілька років. Але частина з них мають постійні витрати, частина змінні.

Основними проектами ПрАТ «МХП» у 2020 році були такі, як: постійно діючий Благодійний фронд «МХП-громаді» (допомога тим людям, які цього потребують); Центр активного довголіття; підтримка діяльності пересувної амбулаторії у рамках програми «Лікар для села»; заснування та підтримка об'єднавчої платфрорми «Спільнодія» для боротьби з короновірусом [6]. Крім того підприємством втілено проєкт щодо збереження навколишнього середовища - побудовано біогазову установку для відпрацювання курячого посліду (вартість проекту на момент реалізації 98 млн. євро).

У свою чергу, основними проектами Вінницької кондитерська фрабрика РОШЕН у 2020 році, представники департаменту міжнародного співробітництва та регіонального розвитку, вказують на постійну реалізацію масштабних та системних благодійних та соціально-культурних проектів, серед яких відзначають такі: придбання для лікарень понад 100 тисяч костюмів і комбінезонів індивідуального захисту медперсоналу, портативних ренген-апаратів, нітрилових рукавичок; фрінансування придбання 25000 продуктових наборів «Життєлюб» для літніх людей, вартістю 225 грн. за один; технічне обслуговування, консервація фронтана на зиму, підготовка конструкції до нового сезону навесні у місті Вінниці.
Більшість експертів визначаючи основні соціальні проекти зовсім не звертають увагу, не зазначаючи інсрормацію на стан мотивування працівників, витрати на їх навчання та удосконалення їх навичок. Наприклад 3 загальної кількості експертів лише експерти ТОВ Люстдорф відзначили, що компанія щорічно організовує заходи спільного відпочинку, соціологічні опитування з метою поліпшення психологічного клімату, залучає тренерів із питань як саморозвитку так і психологічного здоров'я. Варто зазначити, що експерти таких підприємств як: ПрАТ Єврокар, ТОВ Фішер-Мукачево, Джейбіл Сьоркіт Юкрейн Лімітед (Закарпатська обл.), зазначили, що вони реалізують проекти 3 метою створення максимально комфрортних умов роботи для працівників - безкоштовне харчування у заводських їдальнях, есрективне медичне страхування, безкоштовне транспортування працівників в радіусі 40 км від підприємства, безкоштовні курси англійської мови та компютерної грамотності, оплата навчання у вищих навчальних закладах, а також навчання а стажування на заводах компанії та за кордоном. ПАТ «Запоріжсталь» (Запорізька обл.) зі слів експертів спрямовує свою діяльність щодо мотивування своїх працівників додатковими преміями та підтримкою працівників-ветеранів комбінату. ПрАТ «ВО «Стальканат Сілур» (Одеська обл.) націлена на створення умов для профресійного і кар'єрного зростання молоді. Підприємство фрінансує власну фрутбольну команду.

30 \% опитаних зазначили, що пріоритетними вважають проекти щодо забезпечення безпеки праці. До основних інноваційних запропонованих заходів можна віднести такі як: розміщення фото дітей працівників по дорозі до виробничого цеху з метою заклику до виконання правил охорони праці; стимулювання виконання правил безпеки через мотивування та покарання через порушення - пересування розміченими доріжками, тримання за поручні під час руху по сходах, вакцинування від сезонних хвороб. ТОВ Дельта Вілмар Україна (Одеська обл.) визначила пріоритетним напрямком соціальної відповідальності - безпечне робоче місце для працівника. Всі працівники мають можливість безкоштовно харчуватись в їдальні підприємства та користуватись медичним страхуванням.

$24 \%$ анкет експертів містили інформацію щодо охорони навколишнього середо- 
вища, до таких підприємств можна віднести ПрАТ «Миронівський хлібопродукт» (Вінницька обл.), ПрАТ Володимир-Волинська птахофрабрика (Волинська обл.), Українсько-польська компанія «Барлінек» (Вінницька обл.). Наприклад остання з 2000 року запровадила програму, згідно якої здійснюється фрінансування придбання саджанців дуба у якості компенсації за використану сировину. На даний час профрінансовано понад мільйон посадок дубу на території Польщі та України. ПрАТ «Волинь Холдінг» (ТМ «Торчин продукт») задля відповідального ставлення до використання енергоресурсів впровадило проект зміни обладнання на більш енергоесрективне (вартість проекту $120 \mathrm{Mлн.} \mathrm{грн).}$ У 2020 році введено в дію сучасний забійний цех ПрАТ «Володимир-Волинська птахофабрика» (ТМ «Епікур»), що відповідає екологічним вимогам ЄC (вартість проекту 38 млн. євро). ПАТ «Запоріжсталь» (Запорізька обл.) на діагностику та обслуговування газоочисних систем щорічно використовує понад 42 млн. грн. ПрАТ «Запоріжкокс» (Запорізька обл.) поводить масштабну реконструкцію коксових батарей.

Частина експертів зазначають власну участь у загальнодержавних програмах. Так, ПрАТ «Дніпроспецсталь» (Запорізька обл.) $\epsilon$ учасником програми екологічного оздоровлення басейну Дніпра та поліпшення якості питної води. У рамках проекту, підприємством виконано водоохоронні заходи через введення в експлуатацію фрільтру доочистки AMIAD, завдяки якому скидання відпрацьованої технічної води зменшилось на 1 млн м³/piк. Побудовано i запущено насосні системи повернення технічної води в оборотну систему заводу. Це дозволяє скоротити використання чистої води на 500 тис. м³/рік. Соціальна відповідальність ТОВ «Данон-Дніпро» (Херсонська обл.) у сорері охорони довкілля відзначена у рамках виконання глобальної програми «Нуль відходів на сміттєзвалище».

Лише $7 \%$ звернули увагу на необхідність сертифрікації якості пропонованої продукції покупцям. Визнають доцільність такого напрямку соціальної відповідальності - ТОВ Люстдорср (Вінницька обл.), ПрАТ Володимир-Волинська птахофабрика (Волинська обл.), ПрАТ «Теремно продукт» (Волинська обл.) (впровадження системи безпечності харчових продуктів НАСРР - вартість проекту від 75 тис. євро). Фермерське господарство «Органік Сістемс» Холдингу «Агрофьюжн» (Миколаївська обл.) вбачає основним напрямком соціалізації бізнесу випуск та сертисрікація органічної продукції для споживача. А рівні Сумської області відзначили підприємство АТ «Сумський завод Насосенергомаш», яке у 2020 році удостоєно звання «Краще підприємство України» від Національного рейтингу якості товарів і послуг «Зірка Якості» [7]. ПАТ «Бель Шостка України» (Сумська обл.) є загальновизнаним лідером сироваріння у складі групи Bel світового експерта з виробництва сиру. Компанія втілює принципи відповідального виробництва на всіх етапах виготовлення продукції [8].

89 \% схильні до благодійництва у різних напрямках - боротьби з COVID-19, допомога учасникам АТО, особам, які цього потребують. Варто зазначити, що в Україні є підприємства, що майже 100 \% свого прибутку використовують на соціальні цілі. До таких підприємств належить ТОВ «Мерсі Фарм» (Закарпатська обл.), що знаходиться у Закарпатській області. Це підприємство створене благодійним фондом «Дім милосердя» - одним з найбільших благодійних фондів у західній Україні. ТОВ «Сандора» (Миколаївська обл.), яка протягом багатьох років постачає свою продукції у будинки дитини, школи, садочки та приймає участь у значній кількості благодійних соціальних проектах. ТДВ «Інтерхім» (Одеська обл.) спрямовує свої проекти на підтримку та фрінансування благодійних організацій.

$27 \%$ опитаних експертів наводять у структурі впроваджених соціальних заходів проекти націлені на розвиток громад та інфррастуктурні проекти. ПрАТ Екопрод (Донецька обл.) втілює такого роду проекти через благодійний фронд «Агро-Турбота». Варто відзначити ПАТ «Арселор Міттал Берислав» (Херсонська обл.), менеджменту якого впродовж 2020 р. інвестовано у реконструкції навчальних закладів, будинку культури, спортивних майданчиків понад 7 млн. грн.

Жодне із опитаних підприємств не відзначило себе як соціально відповідального платника податків. Хоча у листі відповіді департаменту розвитку економіки ХОДА відзначено ТОВ «Данон-Дніпро», як найбільшого платника податків до місцевого та державних бюджетів.

Тобто, в цілому, лише біля $30 \%$ опитаних респондентів звернули увагу на внутрішні вектори соціальної відповідальності. 3 метою зміни цієї ситуації, доцільно ссрормувати систему показників, яка буде стандартна для всіх. Оцінка стану менеджменту соціальної відповідальності у такій системі сприятиме виявленню проблем, усунення яких сприя- 
тиме підвищенню есрективності як управлінських рішень так і підприємства в цілому.

Висновки із цього дослідження i подальші перспективи в цьому напрямку. Підсумувавши все вище сказане можна зробити такі висновки: через відсутність єдиних критеріїв оцінки немає загальних підходів до оцінювання стану менеджменту соціальної відповідальності; частина експертів не вважають за доцільне оцінювати соціальну від- повідальність за внутрішніми векторами, що може призвести до низької їі ефективності; соціально відповідальною, у переважній більшості, вважається діяльність націлена на доброчинність та великі проекти іміджевого характеру; низький рівень розуміння екологічних проектів як частини соціальної відповідальності бізнесу; нівелювання частини підсистем корпоративної культур підприємства у контексті соціальної відповідальності.

\section{СПИСОК ВИКОРИСТАНИХ ДЖЕРЕЛ:}

1. Березіна О.Ю. Кількісна оцінка соціальної відповідальності корпорацій. Вісник Української академії банківської справи. 2012. № 1(32). С. 97-101.

2. Буян О.А. Підходи до оцінки ефективності корпоративної соціальної відповідальності підприємств в Україні. Вісник Дніпропетровського університету. Серія «Економіка». 2012. № 6(2). С. 159-165.

3. Воробей В. Корпоративна соціальна відповідальність чи вигода? Києво-Могилянська Бізнес-Студія. № 10. 2005. URL: www.Management.com.ua/com/cm037 (дата звернення: 11.11.2020).

4. Ворона О.В. Методичні підходи до оцінки рівня соціальної відповідальності. Вісник економіки транспорту і промисловості. 2010. № 30. С. 127-133.

5. Інфрормаційно аналітичний портал «Ресурси для малого i середнього бізнесу». URL: https://www.uaassets.com.ua (дата звернення: 29.11.2020).

6. Матеріали сайту «Благодійна організація "Благодійний фонд «МХП-Громаді»". URL: https://www.facebook.com/MHPgromadi (дата звернення: 29.11.2020).

7. Офіційний сайт AO «Сумский завод «Насосэнергомаш». URL: https://www.nempump.com (дата звернення: 27.12.2020).

8. Офіційний сайт Групи Бель. URL: https://bel-ukraine.com (дата звернення 13.11.2020).

9. Офріційний сайт Корпоративний реєстр. Глобальні ресурси з KCB. URL: https://corporateregister.com/ (дата звернення: 06.08.2020).

10. Прогнімак О.Д., Іщенко О.Ю., Касперович О.Ю. Формування соціальної відповідальності бізнесу: взаємодія з місцевими спільнотами та владою. URL: http://www.nbuv.gov.ua/portal/soc_gum/Usoc/2006_5/94-105.pdf (дата звернення: 17.11.2020).

11. Євтушенко В.А. Оцінка корпоративної соціальної відповідальності: методи, об'єкти, показники. Вісник НТУ «ХП|». 2013. № 46 (1019). С. 53-63. URL: http://nbuv.gov.ua/UJRN/Vcpitp_2013_46_8 (дата звернення: 06.08.2020).

\section{REFERENCES:}

1. Berezina, O.Yu. (2012) Kil'kisna otsinka sotsial'noyi vidpovidal'nosti korporatsiy [Quantitative assessment of social responsibility of corporations]. Visnyk Ukrayins'koyi akademiyi bankivs'koyi spravy - Bulletin of the Ukrainian Academy of Banking, 1(32), 97-101. (in Ukrainian)

2. Buyan, O.A. (2012) Pidkhody do otsinky efektyvnosti korporatyvnoyi sotsial'noyi vidpovidal'nosti pidpryyemstv $\checkmark$ Ukrayini [Approaches to assessing the effectiveness of corporate social responsibility of enterprises in Ukraine]. Visnyk Dnipropetrovs'koho universytetu. Seriya «Ekonomika» - Bulletin of Dnipropetrovsk University. Economics Series, 6 (2), 159-165 (in Ukrainian)

3. Vorobey, V. (2005) Korporatyvna sotsial'na vidpovidal'nist' chy vyhoda? [Corporate social responsibility or benefit?]. Kyyevo-Mohylyans'ka Biznes-Studiya - Kyiv-Mohyla Business Studio, 10. Retrieved from: www.Management.com.ua/com/cm037 (in Ukrainian)

4. Vorona, O.V. (2010) Metodychni pidkhody do otsinky rivnya sotsial'noyi vidpovidal'nosti [Methodical approaches to assessing the level of social responsibility]. Visnyk ekonomiky transportu i promyslovosti - Bulletin of Transport Economics and Industry, 30, 127-133 (in Ukrainian)

5. Informatsiyno analitychnyy portal «Resursy dlya maloho i seredn'oho biznesu» [Information and analytical portal "Resources for small and medium business"]. Retrieved from: https://www.uaassets.com.ua (in Ukrainian)

6. Materialy saytu «Blahodiyna orhanizatsiya "Blahodiynyy fond "MKHP-Hromadi"» [Materials of the site "Charitable organization" Charitable Foundation "MHP-Community"»]. Retrieved from: https://www.facebook.com/ MHPgromadi (in Ukrainian) 
7. Ofitsiynyy sayt AO «Sumskyy zavod «Nasosénerhomash» [Official site of JSC "Sumy plant" Nasosenergomash"]. Retrieved from: https://www.nempump.com (in Ukrainian)

8. Ofitsiynyy sayt Hrupy Bel' [Official site of the Belle Group]. Retrieved from: https://bel-ukraine.com (in Ukrainian)

9. Ofitsiynyy sayt Korporatyvnyy reyestr. Hlobal'ni resursy z KSV [Official site Corporate Register. Global resources on CSR]. Retrieved from: https://corporateregister.com/ (in Ukrainian)

10. Prohnimak, O.D., Ishchenko, O.YU. \& Kasperovych, O.Yu. Formuvannya sotsial'noyi vidpovidal'nosti biznesu: vzayemodiya z mistsevymy spil'notamy ta vladoyu [Formation of social responsibility of business: interaction with local communities and authorities]. Retrieved from: http://www.nbuv.gov.ua/portal/soc_gum/ Usoc /2006_5/94-105.pdf (in Ukrainian)

11. Yevtushenko, V.A. (2013) Otsinka korporatyvnoyi sotsial'noyi vidpovidal'nosti: metody, obyekty, pokaznyky [Assessment of corporate social responsibility: methods, objects, indicators]. Visnyk NTU «KHPI»-Bulletin of NTU "KhPI", 46 (1019), 53-63. Retrieved from: file:///C:/Users/Asus/Downloads/Vcpitp_2013_46_8.pdf (in Ukrainian) 